\title{
BAC libraries construction from the ancestral diploid genomes of the allotetraploid cultivated peanut
} Patricia M Guimarães *†1, Olivier Garsmeur ${ }^{\dagger 2}$, Karina Proite ${ }^{\dagger 1,3}$, Soraya CM Leal-Bertioli ${ }^{1}$, Guilhermo Seijo ${ }^{4}$, Christian Chaine ${ }^{2}$, David J Bertioli ${ }^{5}$ and Angelique D'Hont ${ }^{2}$

\begin{abstract}
Address: ${ }^{1}$ Biotechnology Unit, Embrapa Genetic Resources and Biotechnology, Brasília, DF, Brazil, ${ }^{2}$ Centre de Coopération International en Recherche Agronomique pour le Developpement (CIRAD), Montpellier, France, ${ }^{3}$ Cell Biology Department, IB-University of Brasília (UnB), Brasília, DF, Brazil, ${ }^{4}$ Plant Cytogenetics and Evolution Laboratory, Instituto de Botánica del Nordeste, Corrientes, Argentina and ${ }^{5}$ Biotechnology and Genomic Sciences Department, Campus II Catholic University of Brasília, Brasília, DF, Brazil

Email: Patricia M Guimarães* - messenbe@cenargen.embrapa.br; Olivier Garsmeur - olivier.garsmeur@cirad.fr; Karina Proite - proite@gmail.com; Soraya CM Leal-Bertioli - soraya@cenargen.embrapa.br; Guilhermo Seijo - jgseijo@yahoo.com; Christian Chaine - christian.chaine@cirad.fr; David J Bertioli - david@pos.ucb.br; Angelique D'Hont - angelique.dhont@cirad.fr

* Corresponding author †Equal contributors
\end{abstract}

Published: 29 January 2008

BMC Plant Biology 2008, 8:14 doi:10.1186/147|-2229-8-14
Received: 30 August 2007

Accepted: 29 January 2008

This article is available from: http://www.biomedcentral.com/I47I-2229/8/14

(c) 2008 Guimarães et al; licensee BioMed Central Ltd.

This is an Open Access article distributed under the terms of the Creative Commons Attribution License (http://creativecommons.org/licenses/by/2.0), which permits unrestricted use, distribution, and reproduction in any medium, provided the original work is properly cited.

\begin{abstract}
Background: Cultivated peanut, Arachis hypogaea is an allotetraploid of recent origin, with an AABB genome. In common with many other polyploids, it seems that a severe genetic bottle-neck was imposed at the species origin, via hybridisation of two wild species and spontaneous chromosome duplication. Therefore, the study of the genome of peanut is hampered both by the crop's low genetic diversity and its polyploidy. In contrast to cultivated peanut, most wild Arachis species are diploid with high genetic diversity. The study of diploid Arachis genomes is therefore attractive, both to simplify the construction of genetic and physical maps, and for the isolation and characterization of wild alleles. The most probable wild ancestors of cultivated peanut are $A$. duranensis and $A$. ipaënsis with genome types $A A$ and $B B$ respectively.

Results: We constructed and characterized two large-insert libraries in Bacterial Artificial Chromosome (BAC) vector, one for each of the diploid ancestral species. The libraries (AA and $\mathrm{BB}$ ) are respectively c. 7.4 and c. 5.3 genome equivalents with low organelle contamination and average insert sizes of 110 and $100 \mathrm{~kb}$. Both libraries were used for the isolation of clones containing genetically mapped legume anchor markers (single copy genes), and resistance gene analogues.

Conclusion: These diploid BAC libraries are important tools for the isolation of wild alleles conferring resistances to biotic stresses, comparisons of orthologous regions of the $A A$ and $B B$ genomes with each other and with other legume species, and will facilitate the construction of a physical map.
\end{abstract}




\section{Background}

Cultivated peanut (Arachis hypogaea $\mathrm{L}$ ) is the second-most important grain legume crop worldwide after soybean, with a production of 33 million tons in 2003/04 [1]. Peanut is produced throughout the tropics and warmer regions of the subtropics, but is particularly important in Africa, Asia and in the United States [1]. It is an allotetraploid $(\mathrm{AABB})$ of recent origin that arose from hybridization of two wild species and spontaneous chromosome duplication $[2,3]$. This polyploidization event gave rise to a severe genetic bottle-neck [2,3] which has led to lack of variability in some important traits, limited availability of allelic combinations and consequently restrictions in productivity. In addition, the very low level of polymorphism in cultivated peanut has hampered genetic and genomic characterization. In contrast, diploid wild relatives of peanut have high genetic diversity and have been selected during evolution in a range of environments and biotic stresses, constituting a rich source of allele diversity [3]. Wild alleles can be introduced into the gene-pool of cultivated peanut using a "resynthesis" pathway, essentially artificially recreating events similar to those that gave rise to the origin of the crop species [4]. Recent advances in the knowledge of the relationships of wild and cultivated genomes through traditional taxonomy, cytogenetics and molecular studies are enabling new choices of wild species for resynthesis [5-8]. In parallel new genetic and genomic tools (see below) for monitoring the introgression of wild genes into a cultivated background are opening the perspectives for the efficient introgression of wild genes into the peanut crop using molecular breeding.

The very low level of polymorphism in cultivated peanut has hampered genetic mapping and QTL (Quantitative trait loci) studies. Consequently only a few linkage maps have been published. All of them have used wild species to enable the generation of sufficient polymorphic markers. Restriction fragment length polymorphism (RFLP) maps were developed by Halward based on a cross of two AA genome species, A. stenosperma Krapov. \& WC Gregory and A. cardenasii Krapov. \& WC Gregory, and a tetraploid map based on a cross of TxAG-6 (a synthetic amphiploid) and A. hypogaea was published by Burow et al. [9]. Recently, we developed an SSR-based map for the AA genome of Arachis based on a cross of A. stenosperma and A. duranensis Krapov. \& WC Gregory [10] and a map of the BB genome, based on a cross of A. ipaënsis Krapov., WC Gregory \& CE Simpson and A. magna Krapov., WC Gregory \& CE Simpson [11]. Currently there are 54,168 ESTs for A. hypogaea in Genbank [12-14], and 6,264 for the wild AA genome A. stenosperma $[15,16]$.

Bacterial Artificial Chromosome (BAC) libraries are fundamental tools for genomic studies, being important for physical mapping, map-based gene cloning and analysis of gene structure and function. The easy handling and propagation of the clones, their relatively stability and low degree of chimerism compared with yeast artificial chromosome (YAC) vectors have made BAC vectors the cloning system of choice $[17,18]$. A number of strategies have been proposed for physical mapping with largeinsert clones: hybridisation-based methods such as interactive hybridisation using individual cDNA or genomic clones as probes [19], restriction-based fingerprinting methods [20] integrated BAC end sequencing and fingerprint analysis [21] or more recently, the use of oligonucleotide-based "overgos" [22].

Within the Leguminosae, BAC libraries are available for Phaseolus vulgaris [23], Vigna radiata [24], Glycine max [25], Trifolium pretense [26] and the model legumes Lotus japonicus [27] and Medicago truncatula [28]. Within the genus Arachis, one BAC library for the allopolyploid cultivated peanut has been developed [29]. As a complement to this resource, here we describe the production of BAC libraries for the two diploid wild species A. duranensis (AA genome) and A. ipaënsis (BB genome) that have been identified as the most probable ancestors of cultivated peanut $[8,30]$. Using whole genome in-situ hybridization (GISH) we also further investigated the affinities and coverage of the selected diploid genomes compared to those present in A. hypogaea.

\section{Results}

\section{In-situ hybridizations}

Total genomic DNA of $A$. duranensis (AA genome) and A. ipaënsis (BB genome) when used as probes on the chromosomes of $A$. hypogaea displayed intense and uniform hybridization patterns onto AA and BB chromosomes of A. hypogaea respectively (Fig. 1). This clear genome discrimination of the chromosome subsets from the corresponding parental genomes in the tetraploids was possible without the need of any unlabelled blocking DNA, which is normally used to avoid cross-hybridization between a specific probe from one genome and homologous DNA sequences from another genome. Counterstained A and B chromosomes show very similar total sizes for the two genomic components (Fig. 1).

\section{High Molecular Weight (HMW) DNA isolation}

The use of standard HMW DNA isolation protocols [31,32] did not produce sufficient amounts of good quality nuclei for Arachis. High levels of carbohydrate and polyphenols are present in both $A$. duranensis and $A$. ipaënsis leaves. This results in high viscosity leaf extracts, which are difficult to filtrate, increasing considerably the time of the nuclei exposure to the action of oxidizing substances. To overcome this problem, some modifications were necessary: inclusion of PVP-40 in the extraction buffer, filtration of leaf extracts in four layers of cheese- 

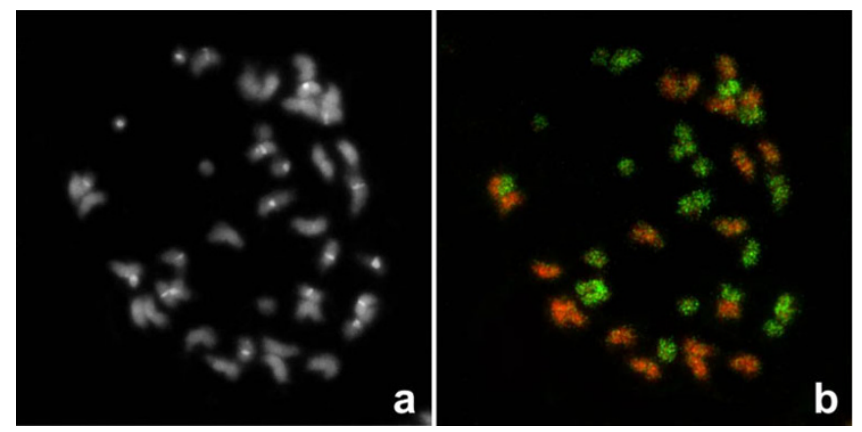

Figure I

GISH of Arachis hypogaea metaphase chromosomes. Somatic metaphases of Arachis hypogaea (subsp. hypogaea var. hypogaea, race Guaycurú) after a) 4'6-diamidino-2-phenylindole (DAPI) counterstaining (blue, shown in black and white), b) Genomic in situ hybridization using genomic DNA from A.duranensis (in green) and A. ipaënsis (red).

cloth followed by two layers of Miracloth, centrifugation at low speed $(60 \times \mathrm{g}$ for $2 \mathrm{~min})$ and a Percoll gradient $(37.5 \%)$. The analysis of the extracts by DAPI-staining microscopy enabled the correct evaluation of the amount and quality of the nuclei preparations.

The inclusion of an extra purification step, consisting of PFGE of agarose plugs for 40 min before digestion, enabled the purging of smaller fragments and eliminated impurities, increasing cloning efficiency. To obtain the highest amount of restricted DNA after electro-elution, only $50 \mu \mathrm{L}$ was recovered at the very bottom of the collection tube instead of $300 \mu \mathrm{L}$ as described in the standard protocol [21]. After the double size selection, various ratios of ligation were tested with the $1 / 4 \mathrm{~V} / \mathrm{I}$ ratio resulting in the greatest number of transformants. Overall, five different ligations were necessary to obtain each BAC library (Table 1).

\section{BAC libraries characterisation}

The BAC library for the AA genome (A. duranensis) contained 84,096 clones whilst the BB genome library (A. ipaënsis) consisted of 75,648 (Table 1). A random sample of each library was analyzed by NotI digestion, and the average insert size was 110 and $100 \mathrm{~kb}$ for A. duranensis and A. ipaënsis respectively (Fig. 2a and 2b; Fig. 3).

The organelle contamination in both BAC libraries was evaluated by screening the high-density filters with mitochondrial and chloroplast specific probes. For A. duranensis, the contamination of BAC clones with chloroplast sequences was of $0.016 \%$ and mitochondrial sequences of $0.21 \%$. For A. ipaënsis $0.363 \%$ was contaminated with chloroplast sequences and $0.081 \%$ of the clones with mitochondrial DNA. These values, together with the microscopic DAPI-staining observations, reflect the high level of purification of the Arachis nuclei obtained with the modified protocol.

Based on the library average insert size and A. duranensis haploid genome, equivalent to $1260 \mathrm{Mb}$ [33], the estimated coverage of the AA genome BAC library is of 7.4 haploid genome equivalents. However, for A. ipaënsis, the DNA-content determination is controversial. It is possible that the haploid genome equivalent of $2,830 \mathrm{Mb}$ reported by Singh et al [34] is a 2.0 fold overestimate because of measurement inconsistencies, as already described for other Arachis species [33,35] Therefore the BB genome BAC library for A. ipaënsis could represent from 2.7 to 5.3 the haploid genome equivalents of the species. Considering that A and B chromosomes show very similar sizes for the two genomic components of the tetraploid (as mentioned above, Fig. 1) we consider that latter to be a better estimate. To further test the coverage, high-density filters were screened with probes corresponding to single copy gene used as anchor markers in legume and that have been placed on the Arachis AA genetic map (unpublished data). An average of 5.1 clones per probe was identified in the AA genome and 4.5 in the $\mathrm{BB}$ (Table 2).

The hybridization of both BAC libraries with an Arachis resistance gene analogue RGA S1_A_36 identified two clones in the $\mathrm{AA}$ genome but none in the $\mathrm{BB}$ genome (Table 2).

\section{Discussion}

Cultivated peanut is an allotetraploid with two nuclear genomic components, AA and BB. Although it is generally agreed that these component genomes are derived from

Table I: Characteristics of the $A$. duranensis and A. ipaënsis BAC libraries

\begin{tabular}{|c|c|c|c|c|c|c|c|}
\hline Species & Ligations(no.) & Genome size $(\mathrm{Mb})$ & Clones (no.) & $\begin{array}{l}\text { Average insert size } \\
(\mathrm{kb})\end{array}$ & mtDNA(\%) & cpDNA(\%) & $\begin{array}{c}\text { Estimated genome } \\
\text { coverage }\end{array}$ \\
\hline A. duranensis & 5 & $1260^{a}$ & 84,096 & 110 & 0.21 & 0.016 & $7.4 \times$ \\
\hline A. ipaënsis & 5 & $1415-2830^{b}$ & 75,648 & 100 & 0.081 & 0.363 & $5.3-2.7^{b} x$ \\
\hline
\end{tabular}

mt: mitochondrial, cp: chloroplastic

a Temsch \& Greilhuber, 2001

b Singh et al, 1996 

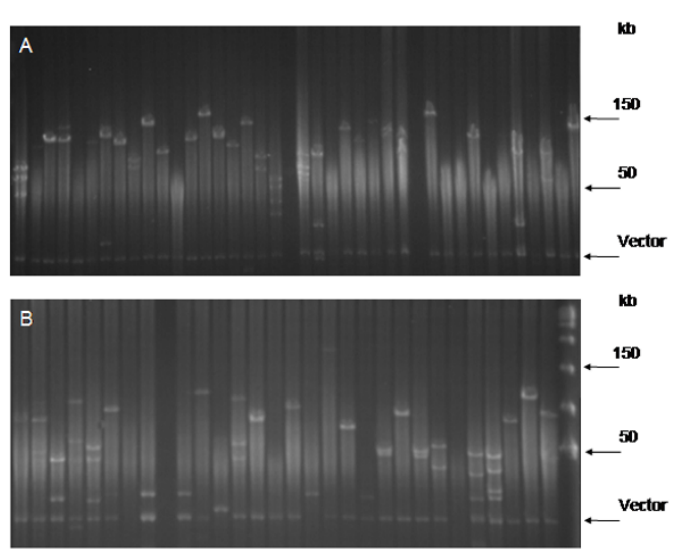

\section{Figure 2}

A. duranensis (a) and $A$. ipaënsis (b) libraries sizing. Random BAC clones from the $A$. duranensis (a) and A. ipaënsis (b) libraries digested with Notl and separated by PGEF. The size of a few reference bands from Lambda Ladder PFG Marker (New England Biolabs) are indicated in kilobases.

diploid wild ancestors, the exact species involved has been a matter of some research and discussion. Although the evidence is not completely clear cut, analysis of data from molecular markers, cytogenetics, morphology and geographical distributions support that $A$. duranensis and $A$. ipaënsis are the direct ancestors of cultivated peanut $[8,30]$.

Genomic in situ hybridization (GISH) of A. hypogaea metaphase chromosomes with total genomic DNA from the AA genome of $A$. duranensis and the $\mathrm{BB}$ genome of $A$. ipaënsis allowed a clear differentiation of the A and B chromosomes. Firstly, this observation reinforces the evidence

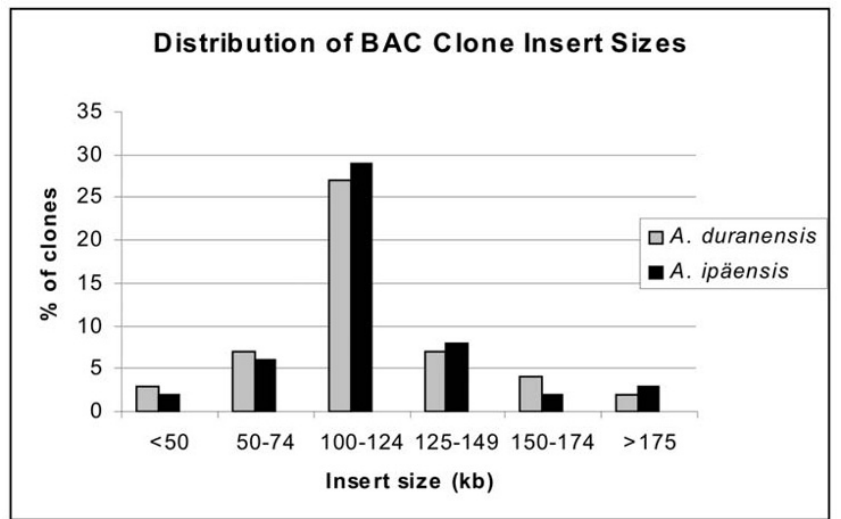

Figure 3

BAC libraries insert sizes. Distribution of insert sizes from randomly selected $B A C$ clones from the $A$. duranensis and $A$. ipaënsis libraries.

of the close relationship between the genomes of $A$. duranensis, A. ipaënsis and cultivated peanut. Secondly, since GISH relies largely on the hybridization of repetitive sequences, it also indicates that A. duranensis and A. ipaënsis genomes have diverged substantially regarding their repeated sequences/transposable elements contents.

In contrast, the evidence available indicates that the gene order in the AA and BB genomes is substantially conserved [9]. This situation of largely syntenic gene frameworks embedded within quickly evolving repetitive DNA seems to be a recurrent theme in plant evolution [36-39].

The availability of BAC libraries from the allopolyploid and the two wild ancestors will allow the comparison of these genomes regarding microsynteny and repetitive DNA contents, in particular transposable elements and will provide insights into the fascinating area of polyploid genome evolution.

Table 2: BAC library filter-hybridization results using legume single-copy probes and one RGA

\begin{tabular}{|c|c|c|}
\hline \multirow[t]{2}{*}{ Probe } & \multicolumn{2}{|c|}{ Number of BAC clones detected } \\
\hline & A. duranensis & A. ipaënsis \\
\hline RGA SI_A_36 & 2 & 0 \\
\hline Leg083 & 2 & 5 \\
\hline Leg 128 & 4 & 4 \\
\hline Leg092, Leg149, LegI78 (mixed) & 19 & \\
\hline Leg 92 & 10 & * \\
\hline Leg237 & 5 & $*$ \\
\hline Leg242 & 6 & * \\
\hline Leg 88 & 0 & * \\
\hline Average Leg clones & 5,11 & 4,5 \\
\hline
\end{tabular}

\footnotetext{
* Not tested
} 
In addition, the legume single copy anchor markers, used to characterize the libraries, will allow orthologous regions to be identified and compared between the AA and BB Arachis genomes, and with other legume genomes, in particular the sequenced genomes of Lotus and Medicago, providing insight into legume genome evolution.

Construction of BAC libraries in some plants can require substantial effort due to particular chemical constitution as already experienced by us before [32]. For Arachis, obtaining good quality HMW DNA was difficult due to contamination from polyphenols and carbohydrates, which are abundant in Arachis leaves. A number of steps had to be added to the standard protocols of nuclei extraction and several ligations had to be made to obtain a reasonable number of BAC clones. These difficulties were also reported by Yuksel and Paterson [29] for the construction of the A hypogaea BAC library.

The genome coverage of the BAC libraries was estimated between 7.4 and 5.1 haploid genome equivalents for the A genome and 5.3 to 4.5 for the B genome. These disparities are due to variations of the density of restriction sites in certain genome regions or difficulties in cloning too large or too small fragments [40]. Considering that 99\% coverage is equivalent to $4.7 \times$ haploid genomes [40]A. duranensis and $A$ ipaënsis genomes are well represented and the libraries will be suitable for many applications.

The availability of BAC libraries from diploid Arachis will greatly facilitate the development of a reference physical map for Arachis. The construction of this physical map will be initiated soon with the A. duranensis BAC library. This species was used as a parent of the mapping population used for the construction of the Arachis SSR-based map [10]. A. ipaënsis is also the parent of a mapping population [11]. This will facilitate the integration of genetic and physical maps.

The exploitation of peanut's diploid wild relatives for breeding is very attractive since they possess various resistances to biotic and abiotic stresses. The two species used to make the BAC libraries harbour resistances to nematode and fungal diseases[41,42]. These new BAC resources will help the tagging and/or the isolation of the corresponding resistance genes. For example, a QTL for resistance to late leaf spot, caused by Cercosporidium personatum has been mapped in a cross of $A$. duranensis with A. stenosperma [43]. S1_A_36, a RGA that co-segregates with this QTL has been used to identify two BAC clones in the A. duranensis library, whilst no clones in the A. ipaënsis library were found. Sequencing of the BAC clones should enable the identification of microsatellites in the target region, thus providing more convenient markers for tracking the QTL in segregating populations.

\section{Conclusion}

In summary, here we describe the production of BAC libraries for the AA and BB genomes of Arachis. The libraries will be a useful resource for the isolation of genes, the construction and correlation of physical and genetic maps, the isolation of probes for cytogenetic analysis, the study of the evolution of the two genome types, and, by comparison with the allotetraploid genome of cultivated peanut, for the study of the evolution of polyploid genomes.

\section{Methods}

\section{Plant Material}

Seeds were obtained from the Arachis germplasm collection, maintained at Embrapa Genetic Resources and Biotechnology - CENARGEN (Brasília-DF, Brazil). The germination was improved by placing the seeds on a blotting paper humidified with a $1 \%$ Ethephon. For HMW DNA isolation, A. duranensis V14167 (genome AA) and A. ipaënsis KG30076 (genome BB) were grown under greenhouse conditions. Young leaves were collected in liquid nitrogen then stored at $-80^{\circ} \mathrm{C}$.

\section{Probe labelling and fluorescent in situ hybridization}

Whole genomic DNA from A. duranensis and A. ipaënsis were used as probes in genomic in situ hybridization (GISH). Probes were labelled with digoxigenin-11-dUTP (Roche, Mannheim, Germany) or biotin-11-dUTP (Sigma) by nick translation.

Pre-treatment of preparations, chromosome and probe denaturation, conditions for the in situ hybridization (hybridization mixes contained DNA probes at a concentration of 2.5-3.5 $\mathrm{ng} / \mu \mathrm{L}$ ), post-hybridization washings, blocking, and indirect detection by fluorochrome conjugated antibodies were performed according to Moscone et al[44]. Antibodies consisted of mouse anti-biotin (Dakopatts, Dako, Carpinteria, California, USA) and sheep antidigoxigenin conjugated to fluorescein isothiocyanate (FITC) (Roche) in PBS $(0.13 \mathrm{~mol} / \mathrm{L} \mathrm{NaCl}, 0.007 \mathrm{~mol} / \mathrm{L}$ $\left.\mathrm{Na}_{2} \mathrm{HPO}_{4}, 0.003 \mathrm{~mol} / \mathrm{L} \mathrm{NaH}_{2} \mathrm{PO}_{4}\right), 3 \%$ (w/v) bovine serum albumin (BSA) or, rabbit anti-mouse conjugated to tetramethyl-rodamine isothiocyanate (TRITC) (Dakopatts) and FITC-conjugated rabbit anti-sheep (Dakopatts) in PBS, 3\% (w/v) BSA. Preparations were counterstained and mounted with Vectashield medium (Vector Laboratories, Burlingame, California, USA) containing $2 \mu \mathrm{g} / \mathrm{mL}$ of 4',6-diamidino-2-phenylindole (DAPI, Sigma).

The DAPI counterstaining subsequent to GISH resulted in a C banding-like pattern with major heterochromatin bands fluorescing more intensely, thus aiding chromosome identification $[8,44]$. 


\section{Fluorescence microscopy and image acquisition}

Chromosomes were viewed and photographed with a Leica DMLB fluorescence microscope (Leica, Heerbrugg, Switzerland) equipped with a computer-assisted Leica DC 250 digital camera system. Red, green, and blue images were captured in black and white using appropriate filters for TRITC, FITC, and DAPI excitation, respectively. Digital images were pseudo-coloured and combined using IM 1000 Leica software, then imported into Adobe Photoshop, version 7.0 (Adobe, San Jose, California, USA) for final processing.

\section{HMW DNA isolation}

Nuclei were isolated from leaves according to Meyers et al. [31] with some modifications. Fifty grams of young leaves were ground in liquid nitrogen and nuclei were liberated by incubating the cell extract at $4^{\circ} \mathrm{C}$ for $20 \mathrm{~min}$ in $\mathrm{HB} 1 \times$ extraction buffer, plus $0.2 \%$ of polyvinylpyrrolidone (PVP 40). PVP was added to the buffer to reduce the production of oxidizing polyphenolic substances. To eliminate cell debris, the leaf homogenate was filtered successively through four layers of cheesecloth then two layers of Miracloth $(250 \mu \mathrm{m})$, (Calbiochem, UK) and a low speed centrifugation $(60 \times \mathrm{g}$ for $2 \mathrm{~min})$ was performed. Centrifugation at $850 \times \mathrm{g}$ for $8 \mathrm{~min}$ at $4{ }^{\circ} \mathrm{C}$ was followed by a Percoll gradient (37.5\%) to separate nuclei from the pectin matrix [45]. The nuclei was washed in $20 \mathrm{~mL}$ of $\mathrm{HB}$ $1 \times$ extraction buffer without $\beta$-mercaptoethanol and Triton-100 $\times$, and then centrifuged at $850 \times \mathrm{g}$ for $8 \mathrm{~min}$ at $4^{\circ} \mathrm{C}$. Finally the nuclei pellet was resuspended in $1 \mathrm{~mL}$ of filtered HB $1 \times$ and embedded in 1.2\% low-melting-point agarose plugs (InCert Agarose, Cambrex-Bioscience, Rockland, Inc.). An aliquot of the nuclei extraction was evaluated under a microscope using DAPI staining to observe the integrity of the nuclei and the purity of the preparation in terms of organelle contamination. Agarose plugs containing HMW DNA were incubated for $24 \mathrm{~h}$ at $50^{\circ} \mathrm{C}$ in lysis buffer (5\% Sodium Lauryl Sarcosyl, $0.625 \mathrm{M}$ EDTA $\mathrm{pH}$ 9.0, $50 \mathrm{mg}$ Proteinase $\mathrm{K}$ ), washed for $1 \mathrm{~h}$ at $4^{\circ} \mathrm{C}$ in inactivation solution (0.5 M EDTA, pH 8.0, $1 \mathrm{mM}$ PMSF), then washed four times for $30 \mathrm{~min}$ in TE 10/10 (10 mM Tris-HCl, 10 mM EDTA, pH 8.0). An extra HMW DNA purification step was conducted with a pulsed-field gel electrophoresis (PFGE) using a CHEF Mapper ${ }^{\mathrm{TM}} \mathrm{XA}$ apparatus (Bio-Rad, U.K.) at $6 \mathrm{~V} / \mathrm{cm}$, with $3 \mathrm{~s}$ of switch time, and an angle of $120^{\circ}$ for $40 \mathrm{~min}$ aiming to eliminate the degraded DNA. Agarose plugs were finally washed four times for $30 \mathrm{~min}$ in TE $10 / 1(10 \mathrm{mM}$ Tris-HCl, $1 \mathrm{mM}$ EDTA, pH 8.0). at $4{ }^{\circ} \mathrm{C}$ before being used for restriction enzyme digestions.

\section{BAC library construction}

Agarose plugs containing HMW DNA were chopped into small pieces and incubated on ice, with agitation, three times in $1 \mathrm{~mL}$ of HindIII restriction buffer (Gibco BRL,
USA), with buffer exchange every $30 \mathrm{~min}$. Seven units of HindIII was added to each chopped plug and allowed to diffuse for 4 hours on ice. For partial digestions, the reactions were incubated for $15 \mathrm{~min}$ at $37^{\circ} \mathrm{C}$ and then stopped by adding one-tenth of the total volume of $0.5 \mathrm{M}$ EDTA, pH 8.0. Partially digested HMW DNA was sizeselected by two successive PFGE in 1\% GTG SEAKEM agarose gels in $0.5 \times \mathrm{TBE}$ at $14^{\circ} \mathrm{C}$. The first-sizing was performed at $6 \mathrm{~V} / \mathrm{cm}$, with $1 \mathrm{~s}$ to $50 \mathrm{~s}$ of switch-time, and an angle of $120^{\circ}$ for $20 \mathrm{~h}$. Two regions from 80 to $150 \mathrm{~kb}$ and 150 to $250 \mathrm{~kb}$ were excised from the gel and loaded onto a new gel. The second-sizing selection was then performed at $6 \mathrm{~V} / \mathrm{cm}$, with $3 \mathrm{~s}$ of switch time, and an angle of $120^{\circ}$ for $20 \mathrm{~h}$. The regions from 100 to $250 \mathrm{~kb}$ were cut out from the latter gel and the DNA was recovered through an electro-elution (BIO-RAD/electro-eluter, UK). DNA concentration was estimated in $1 \%$ agarose gel in $1 \times$ TAE. Several ligation reactions were tested containing different ratios of vector to insert. A constant $30 \mathrm{ng}$ of the commercial vector "pIndigo BAC-5 HindIII-Cloning Ready" (Epicentre, USA) was used, and varying amounts of DNA ranging from 50 to $600 \mathrm{ng}$ of HMW DNA were used. One microlitre of ligation was mixed to 20 microlitres of competent E. coli cells (ElectroMAX DH10B, Invitrogen) and electro-transformed using a BRL Cell-Porator system according to the manufacturer's recommendations but with a charge rate of 355 volts. Transformants were selected on 2YT plates (tryptone $16 \mathrm{~g} / \mathrm{L}$, yeast extract $10 \mathrm{~g} /$ $\mathrm{L}$, sodium chloride $5 \mathrm{~g} / \mathrm{L}$, agar $16 \mathrm{~g} / \mathrm{L}$ ) containing $12.5 \mu \mathrm{g} /$ $\mathrm{mL}$ of chloramphenicol, $50 \mu \mathrm{g} / \mathrm{mL}$ of 5 -bromo- 4 -chloro3 -indole- $\beta$-D-galactopyranoside (X-Gal) and $25 \mu \mathrm{g} / \mathrm{mL}$ of isopropyl-thiogalactoside (IPTG). White colonies were picked using a Q-Pix 2 colony picker robot (Genetix) and transferred to 384-well plates containing $80 \mu \mathrm{L}$ of $2 \mathrm{YT}, 7 \%$ glycerol. Microplates were incubated for $18-20 \mathrm{~h}$ at $37^{\circ} \mathrm{C}$ and stored at $-80^{\circ} \mathrm{C}$.

\section{BAC library screening and DNA isolation}

For estimation of BAC clone insert sizes, random individual clones were grown in $100 \mu \mathrm{L}$ pre-innoculum and then in $3 \mathrm{~mL} 2 \mathrm{YT}$ liquid medium containing chloramphenicol $(12.5 \mu \mathrm{g} / \mathrm{mL})$. BAC DNA was isolated using a QIAGEN BIO-ROBOT 9600 (Qiagen GmbH, Germany). BAC DNA was digested with NotI to release the inserts. The digested clones were separated by PFGE at $6 \mathrm{~V}$, a switch time from 5 to $15 \mathrm{~s}$, an angle of $120^{\circ}$ and run for $15 \mathrm{~h}$. High-density filters were made using a Q-Pix 2 robot (Genetix). Each high-density filter contained 18,432 double-spotted clones. Hybridisations were performed as described in the Clemson BAC protocols [45]. Filters were exposed for 24 h to Ferrania LifeRay XCG-films.

\section{Genomic probes}

Estimation of organelle contamination in both libraries was evaluated by hybridization of high-density filters 
using probes from a spinach chloroplast gene, the large Rubisco subunit $(1.5 \mathrm{~kb})$ and a wheat mitochondrial gene of cytochrome oxidase cox I (1.3 kb) [32]. BAC libraries were also hybridized to probes from single-copy genes that have been defined as legume anchor markers [46] and the Arachis resistance gene analogue S1_A_36 [47] (Genbank accession AY157808). This RGA was isolated from the AA genome species A. stenosperma and has been found to co-localize with a QTL for resistance to the lateleaf spot Cercosporidium personatum [43].

\section{Authors' contributions}

PMG conceived the study, constructed the libraries and drafted the manuscript. KP constructed the libraries and participated in planning the experiments. OG adapted the BAC library construction protocol to Arachis, constructed the libraries, and contributed to the writing of the manuscript. SCLB conceived the study, contributed resources and participated in drafting the manuscript. GS conducted the cytogenetic experiments. CC was responsible for the maintenance of the plants in greenhouse. DJB conceived and coordinated the study and drafted the manuscript. ADH contributed materials and resources, coordinated libraries construction and contributed to the writing of the manuscript. All authors read and approved the manuscript.

\section{Acknowledgements}

This work was funded by the Generation Challenge Program (Project \#3I) and host institutions. Karina Proite had a doctoral fellowship granted by the Coordenação de Aperfeiçoamento de Pessoal de Nível Superior (CAPES).

The authors would like to thank Dr. José.F.M.Valls for his valuable advice and for providing seeds from EMBRAPA's Germplasm Bank, also thanks are due to Xavier Sabau for robotic technical assistance.

\section{References}

I. FAO: FAOSTAT Agriculture. 2003.

2. Young ND, Weeden NF, Kochert G: Genome mapping in legumes (Family Fabaceae). In Genome mapping in plants Edited by: Paterson AH LRG. Austin ; 1996.

3. Halward TM, Stalker HT, Kochert G: Development of an RFLP linkage map in diploid peanut species. Theoretical and Applied Genetics 1993, 87:379-384.

4. Simpson CE, Starr JL, Church GT, Burrow MD, Paterson AH: Registration of NemaTAM peanut. Crop Science 2003, 43: 1561 .

5. Singh AK, Smartt J: The genome donors of the groundnut/peanut (Arachis hypogaea L.) revisited. Genetic Resources and Crop Evolution 1998, 45: II3-118.

6. Moretzsohn MC, Hopkins MS, Mitchell SE, Kresovich S, Valls JF, Ferreira ME: Genetic diversity of peanut (Arachis hypogaea $L$.) and its wild relatives based on the analysis of hypervariable regions of the genome. BMC Plant Biology 2004, 4:II.

7. Valls JFM, Simpson CE: New species of Arachis L. (Leguminosae) from Brazil, Paraguay and Bolivia. Bonplandia 2005, 14:35-64.

8. Seijo JG, Lavia GI, Fernández A, Krapovickas A, Ducasse D, Moscone EA: Physical mapping of the 5S and 18S-25S rRNA genes by FISH as evidence that Arachis duranensis and $A$. ipaënsis are the wild diploid progenitors of A. hypogaea (leguminosae). American Journal of Botany 2004, 9 I: 1294-1303.

9. Burow MD, Simpson CE, Starr JL, Paterson AH: Transmission genetics of chromatin from a synthetic amphidiploid to cultivated peanut (Arachis hypogaea L.). broadening the gene pool of a monophyletic polyploid species. Genetics 200I, I59(2):823-837.

10. Moretzsohn MC, Leoi L, Proite K, Guimaraes PM, Leal-Bertioli SC, Gimenes MA, Martins WS, Valls JF, Grattapaglia D, Bertioli DJ: A microsatellite-based, gene-rich linkage map for the AA genome of Arachis (Fabaceae). Theoretical and Applied Genetics 2005, I I I(6): I060-I07I.

II. Gobbi A, Teixeira C, Moretszohn M, Guimarães PM, Leal-Bertioli S, Bertioli D, Lopes CR, Gimenes MA: Development of a linkage map to species of $B$ genome related to the peanut (Arachis hypogaea-AABB) : San Diego, Califórnia. ; 2006:679.

12. Luo M, Liang XQ, Dang P, Holbrook CC, Bausher MG, Lee RD, Guo $B Z$ : Microarray-based screening of differentially expressed genes in peanut in response to Aspergillus parasiticus infection and drought stress. Plant Science 2005, 169:695-703.

13. Luo M, Dang P, Bausher MG, Holbrook CC, Lee RD, Lynch RE, Guo $B Z$ : Identification of transcripts involved in resistance responses to leaf spot disease caused by Cercosporidium personatum in peanut (Arachis hypogaea). Phytopathology 2005, 95:38I-387.

14. Luo M, Dang P, Guo BZ, He G, Holbrook C, Bausher MG, Lee RD: Generation of Expressed Sequenced tags (ESTs) for gene discovery and marker development in cultivated peanut. Crop Science 2005, 45:346-353.

15. Proite K, Leal-Bertioli SC, Bertioli DJ, Moretzsohn MC, da Silva FR, Martins NF, Guimaraes PM: ESTs from a wild Arachis species for gene discovery and marker development. BMC Plant Biology 2007, 7:7.

16. Martins W, de Sousa D, Proite K, Guimaraes P, Moretzsohn M, Bertioli $D$ : New softwares for automated microsatellite marker development. Nucleic Acids Research 2006, 34(4):e3I.

17. Dvorak J, Yang ZL, You FM, Luo MC: Deletion polymorphism in wheat chromosome regions with contrasting recombination rates. Genetics 2004, 168(3): 1665-1675.

18. Chalhoub B, Belcram H, Caboche M: Efficient cloning of plant genomes into bacterial artificial chromosome (BAC) libraries with larger and more uniform insert size. Plant Biotechnology Journal 2004, 2(3): $181-188$.

19. Mozo T, Dewar K, Dunn P, Ecker JR, Fischer S, Kloska S, Lehrach H, Marra M, Martienssen R, Meier-Ewert S, Altmann T: A complete BAC-based physical map of the Arabidopsis thaliana genome. Nature Genetics 1999, 22(3):27|-275.

20. Hong G: A rapid and accurate strategy for rice contig map construction by combination of fingerprinting and hybridization. Plant Molecular Biology 1997, 35( I-2): I 29-133.

21. Mayer K, Schuller C, Wambutt R, Murphy G, Volckaert G, Pohl T, Dusterhoft A, Stiekema W, Entian KD, Terryn N, Harris B, Ansorge W, Brandt P, Grivell L, Rieger M, Weichselgartner M, de Simone V, Obermaier B, Mache R, Muller M, Kreis M, Delseny M, Puigdomenech P, Watson M, Schmidtheini T, Reichert B, Portatelle D, Perez-Alonso M, Boutry M, Bancroft I, Vos P, Hoheisel J, Zimmermann W, Wedler $\mathrm{H}$, Ridley P, Langham SA, McCullagh B, Bilham L, Robben J, Van der Schueren J, Grymonprez B, Chuang YJ, Vandenbussche F, Braeken M, Weltjens I, Voet M, Bastiaens I, Aert R, Defoor E, Weitzenegger T, Bothe G, Ramsperger U, Hilbert H, Braun M, Holzer E, Brandt A, Peters S, van Staveren M, Dirske W, Mooijman P, Klein Lankhorst R, Rose M, Hauf J, Kotter P, Berneiser S, Hempel S, Feldpausch M, Lamberth S, Van den Daele H, De Keyser A, Buysshaert C, Gielen J, Villarroel R, De Clercq R, Van Montagu M, Rogers J, Cronin A, Quail M, Bray-Allen S, Clark L, Doggett J, Hall S, Kay M, Lennard N, McLay K, Mayes R, Pettett A, Rajandream MA, Lyne M, Benes V, Rechmann S, Borkova D, Blocker H, Scharfe M, Grimm M, Lohnert TH, Dose S, de Haan M, Maarse A, Schafer M, Muller-Auer S, Gabel C, Fuchs M, Fartmann B, Granderath K, Dauner D, Herzl A, Neumann S, Argiriou A, Vitale D, Liguori R, Piravandi E, Massenet O, Quigley F, Clabauld G, Mundlein A, Felber R, Schnabl S, Hiller R, Schmidt W, Lecharny A, Aubourg S, Chefdor F, Cooke R, Berger C, Montfort A, Casacuberta E, Gibbons T, Weber N, Vandenbol M, Bargues M, Terol J, Torres A, Perez-Perez A, Purnelle B, Bent E, Johnson S, Tacon D, Jesse T, Heijnen L, Schwarz S, Scholler P, Heber S, Francs P, Bielke C, Frishman D, Haase D, Lemcke K, Mewes HW, Stocker S, Zaccaria P, Bevan M, Wilson RK, de la Bastide M, Habermann K, Parnell L, Dedhia N, Gnoj L, Schutz K, Huang E, Spiegel L, Sehkon M, Murray J, Sheet P, Cordes M, Abu-Threideh J, Stoneking T, Kalicki J, Graves T, Harmon G, Edwards J, Latreille P, Courtney L, Cloud J, Abbott A, Scott K, Johnson D, Minx P, Bentley D, Fulton B, Miller N, Greco T, Kemp K, 
Kramer J, Fulton L, Mardis E, Dante M, Pepin K, Hillier L, Nelson J, Spieth J, Ryan E, Andrews S, Geisel C, Layman D, Du H, Ali J, Berghoff A, Jones K, Drone K, Cotton M, Joshu C, Antonoiu B, Zidanic M, Strong C, Sun H, Lamar B, Yordan C, Ma P, Zhong J, Preston R, Vil D, Shekher M, Matero A, Shah R, Swaby IK, O'Shaughnessy A, Rodriguez M, Hoffmann J, Till S, Granat S, Shohdy N, Hasegawa A, Hameed A, Lodhi M, Johnson A, Chen E, Marra M, Martienssen R, McCombie WR: Sequence and analysis of chromosome 4 of the plant Arabidopsis thaliana. Nature 1999, 402(6763):769-777.

22. Gardiner J, Schroeder S, Polacco ML, Sanchez-Villeda H, Fang Z, Morgante M, Landewe T, Fengler K, Useche F, Hanafey M, Tingey S, Chou $\mathrm{H}$, Wing R, Soderlund C, Coe EH Jr.: Anchoring 9,37I maize expressed sequence tagged unigenes to the bacterial artificial chromosome contig map by two-dimensional overgo hybridization. Plant Physiology 2004, 134(4): |3|7-1326.

23. Vanhouten $W$, MacKenzie S: Construction and characterization of a common bean bacterial artificial chromosome library. Plant Molecular Biology 1999, 40(6):977-983.

24. Miyagi M, Humphry M, Ma ZY, Lambrides CJ, Bateson M, Liu C]: Construction of bacterial artificial chromosome libraries and their application in developing PCR-based markers closely linked to a major locus conditioning bruchid resistance in mungbean (Vigna radiata L. Wilczek). Theoretical and Applied Genetics 2004, I I0(I): I5I-I56.

25. Danesh D, Peñuela S, Mudge J, Denny RL, Nordstrom H, Martinez JP, Young ND: A bacterial artificial chromosome library for soybean and identification of clones near a major cyst nematode resistance gene. Theoretical and Applied Genetics 1998, 96: 196-202.

26. Sato $S$, Isobe $S$, Asamizu $E$, Ohmido $N$, Kataoka R, Nakamura $Y$, Kaneko T, Sakurai N, Okumura K, Klimenko I, Sasamoto S, Wada T, Watanabe A, Kohara M, Fujishiro T, Tabata S: Comprehensive Structural Analysis of the Genome of Red Clover (Trifolium pratense L.). DNA Research 2005, I 2(5):30I-364.

27. Kawasaki S, Murakami Y: Genome Analysis of Lotus japonicus. Journal of Plant Research 2000:0918-9440.

28. Nam YW, Penmetsa RV, Endre G, Uribe P, Kim D, Cook DR: Construction of a bacterial artificial chromosome library of Medicago truncatula and identification of clones containing ethylene-response genes. Theoretical and Applied Genetics 1999, 98:3-4.

29. Yuksel B, Paterson AH: Construction and characterization of a peanut HindIII BAC library. Theoretical and Applied Genetics 2005, I I I(4):630-639.

30. Kochert G, Stalker HT, Gimenes M, Galgaro L, Lopes CR, Moore K: RFLP and cytogenetic evidence on the origin and evolution of allotetraploid domesticated peanut Arachis hypogaea (Leguminosae). American Journal of Botany 1996, 83:1282-II291.

31. Zhang HB, Zhao X, Ding X, Paterson AH, Wing RA: Preparation of megabase-size DNA from plant nuclei. Plant Journal 1995, 7:175-184.

32. Vilarinhos $A D$, Piffanelli $P$, Lagoda $P$, Thibivilliers $S$, Sabau $X$, Carreel $F, D$ 'Hont $A$ : Construction and characterization of a bacterial artificial chromosome library of banana (Musa acuminata Colla). Theor Appl Genet 2003, 106(6): I I02-1 I06.

33. Temsch EM, Greilhuber J: Genome size in Arachis duranensis: a critical study. Genome 200I, 44(5):826-830.

34. Singh KP, Raina SN, Singh AK: Variation in chromosomal DNA associated with the evolution of Arachis species. Genome 1996, 39:890-897.

35. Temsch EM, Greilhuber J: Genome size variation in Arachis hypogaea and A. monticola re-evaluated. Genome 2000, 43(3):449-45I.

36. Gale MD, Devos KM: Plant Comparative Genetics after 10 Years. Science 1998, 282:656-658.

37. McCouch SR: Genomics and Synteny. Plant Physiology 200I, I25: I52-I55.

38. Lonnig WE, Saedler $\mathrm{H}$ : Chromosome rearrangements and transposable elements. Annual Review of Genetics 2002, 36:389-410.

39. Kazazian HH Jr.: Mobile elements: drivers of genome evolution. Science 2004, 303(5664): $1626-1632$.

40. Zhang HB, Wu C: BAC as tools for genome sequencing. Plant Physiology and Biochemistry 200I, 39:195-209.

41. Subrahmanyam P, McDonald D, Gibbons RW, Subba RPV: Components of resistance to Puccinia arachidis in peanuts. Phytopathology 1983:253-256.
42. Nelson SC, Simpson CE, Starr JL: Resistance to Meloidogyne arenaria in Arachis spp. germplasm. Journal of Nematology 1989 , 21():654-660.

43. Moretzsohn MC: Desenvolvimento e mapeamento de marcadores microssatélites e identificação de QTLs ligados à produtividade e à resistência à mancha preta em Arachis spp. In Molecular Biology Volume Doctoral Thesis. Brasília, Universidade de Brasília; 2006: 142

44. Moscone EA, Klein F, Lambrou M, Fuchs J, Schweizer D: Quantitative karyotyping and dual-color FISH mapping of $5 \mathrm{~S}$ and I 8S25S rDNA probes in the cultivated Phaseolus species (Leguminosae). Genome 1999, 42(6): 1224-1233.

45. Peterson DG, Tomkins JP, Frisch DA, Wing RA, Paterson AH: Construction of plant bacterial artificial chromosome (BAC) libraries: an illustrated guide. Journal of Agricultural Genomics 2000, 5:.

46. Fredslund J, Madsen LH, Hougaard BK, Nielsen AM, Bertioli D, Sandal $\mathrm{N}$, Stougaard J, Schauser L: A general pipeline for the development of anchor markers for comparative genomics in plants. BMC Genomics 2006, 7:207.

47. Bertioli DJ, Leal-Bertioli SC, Lion MB, Santos VL, Pappas G Jr., Cannon SB, Guimaraes PM: A large scale analysis of resistance gene homologues in Arachis. Molecular Genetics and Genomics 2003, 270(1):34-45.
Publish with Biomed Central and every scientist can read your work free of charge

"BioMed Central will be the most significant development for disseminating the results of biomedical research in our lifetime. "

Sir Paul Nurse, Cancer Research UK

Your research papers will be:

- available free of charge to the entire biomedical community

- peer reviewed and published immediately upon acceptance

- cited in PubMed and archived on PubMed Central

- yours - you keep the copyright
BioMedcentral 